\title{
Concluding Remarks on Economic Policy
}

\begin{abstract}
The German debt brake is not compatible with the long-term stability of the euro. "New thinking" requires that public debt and price stability are no longer opponents, but rather allies in the Keynes world of persistently low interest rates. The proposed balanced account agreement is made more concrete here: An appropriate target (real) interest rate on the global capital market is between one and $1.5 \%$ per year lower than the growth rate of the OECD plus China region. If the actual interest rate is below the target rate, the countries with current account surpluses undertake to increase their public debt period $D$ gradually according to a definite formula. In symmetrical fashion, if the real interest rate is "too high," countries with current account deficits have the duty to reduce their public debt period. The rules of the balanced account agreement replace the debt brake. They are the instruments of sound fiscal policy.
\end{abstract}

\subsection{Summary Part 1: Economic Policy in Germany, Europe and the World}

In the second part of our book, we have examined some questions on international economic policy that derive from the fact of the Great Divergence. The economic policy of democratic countries is conducted under the conditions of political economy: i.e., under the conditions for having electoral success among citizens. In Chap. 10, we put forward the following basic thesis: The level of the natural rate of interest has a decisive influence on the relative weight of voters' interests as producers and their interests as consumers. With a falling natural rate, the weight of their interests as producers rises. This analysis explains the "Trump phenomenon" and especially the new wave of protectionism. Today, the strongest card that a nation can play in the international game of trade relations is the access of other 
nations to its own internal market. And this card is all the stronger, the bigger that internal market is - and the American internal market is very big. Thus, in a "Keynes world," we arrive at new international rules: at a "New Trade Policy."

This led us in Chap. 10 to propose a balanced account agreement: The rules of global free trade (the WTO and related multilateral negotiations on cutting tariffs) should be supplemented and thus politically reinforced by an international obligation for countries to use their fiscal policies to bring about balanced current accounts. In a "Friedman world" with high real interest rates, it is the duty of countries with current account deficits to bring their current accounts into balance by reducing their public debt. In a "Keynes world" with low real interest rates, it is the duty of countries with current account surpluses to bring their current accounts into balance by way of increased public debt. In the "Keynes world," the citizens of all countries will thus be able to understand that international trade and globalization "distribute jobs fairly" around the world. And an electoral majority in each country will thus become convinced that the benefits of globalization and the free movement of goods are greater than the costs.

Such a balanced account agreement merely obliges countries to adopt a fiscal policy that is in their own interest in any case. At low real interest rates, additional public debt is not a burden for the future and future generations in countries that are presently running current account surpluses. This is the charm of the "dynamic inefficiency" that goes along with these low interest rates: More consumption today does not have to be purchased with less consumption in future. And more public investment today is even an additional bonus for future generations. And vice versa: At the high real interest rates of a "Friedman world," the obligation for countries with current account deficits to reduce their public debt is in their own interest in any case.

Chapter 11 was, above all, about Europe. One of the effects of the euro is to eliminate countries' temptation to obtain (temporary) competitive advantages for their own industry by devaluing the national currency. In the Keynes world, it is thus also an obstacle to concluding bilateral "deals" with non-European powers at the expense of the other EU member states. In this way, the euro is also a pillar of the European single market. But this is particularly significant in the age of the "New Trade Policy," because, given the size of the European single market, access to it is a particularly strong card in international trade negotiations.

To stabilize the euro politically, the balanced account agreement has also to be applied to the individual current accounts of the countries in the eurozone. Populists in the Mediterranean eurozone countries see the euro as a German tool for selling German goods as cheaply as possible at the expense of jobs in the South of Europe. As crude as the economics of this view may be, one has to acknowledge that it is right on one point, which is also emphasized by the US government: The weakness of the southern euro countries makes the exchange rate of the euro far lower than, for example, that of a euro limited to the northern members would be. And this helps German exports. 
Moreover, the following has also to be taken into account. Let us assume that nothing changes in the basic outlines of the present fiscal policy of the eurozone countries. What then would a euro area in which there is pervasive full employment look like? Given its demography, it would undoubtedly be characterized by a massive excess of private saving (in the conventional sense, i.e., not including contributions to social security programs) over private investment, which would thus be reflected in high trade surpluses. But this precisely will not come to pass, because such a strong currency would appreciate massively. And this would make precisely these trade surpluses impossible. And in the age of the "New Trade Policy," holding the exchange rate of the euro low by way of massive dollar purchases by the ECB is out of the question. The USA (and soon probably China as well) could "veto" such a move, threatening otherwise to impose tariffs in retaliation.

In light of the success of politicians like Matteo Salvini, we cannot expect a country like Italy to remain in the euro, if this impossibility of full employment in the euro area becomes widely known. But this means that Germany's debt brake is not compatible with the stability of the euro. Only a significantly more expansionary fiscal policy in the "strong" euro countries can save the euro in a world that can be expected to remain a "Keynes world" for the foreseeable future. The "strong" euro countries, led by Germany, would thus have to increase their deficits, in order to allow the "weak" euro countries to reduce their debt levels without excessive "austerity" and, moreover, to find remaining in the euro area "enjoyable." It is, in a sense, "by accident" and not thanks to wise planning that Covid-19induced public deficits are leading to a higher German debt period $D$.

In the context of a changed fiscal policy in the spirit of the proposed "balanced account agreement," Germany can, of course, insist that it will not intervene on behalf of the public debt of other eurozone countries. This would (finally!) fulfill a promise that Germany's Christian Democrats and other German parties made in the late 1990s, when pleading with German voters not to get into a funk because of the departure of the D-mark.

At low interest rates, a more expansionary fiscal policy could be used for public investment that is primarily aimed at bringing about German demographic renewal. We refer here to Sect. 11.8. For us, it is a paradox that when the United Nations is forecasting considerable growth in the global population for the entire twenty-first century, the official German outlook, based on the population projections of the Federal Statistical Office, is that of a secular decline in population. It seems to us that greater demographic realism is required here. A comparatively well-functioning country with a competitive economy cannot avoid being involved in the migratory movements that are increasingly occurring around the world. The German state (including federal, regional and local authorities) should not put its head in the sand, but rather actively shape net immigration - also for the benefit of the native population - and it should invest massively in doing so. It is well known that Germany has a great need for skilled workers at the moment. And for demographic reasons, it is even more evident that in future, Germany will only be able to obtain a sufficient number of skilled workers via immigration from other countries. 
If Germany decides to join such a balanced account agreement, then there will be a public debate about how the required deficit spending should be used. Depending on the political orientation of the government, it could be used for increased efforts to improve education, increased expansion of rail and road networks, increased efforts to improve the health care system, increased efforts to give the Bundeswehr a genuine operational capability, increased efforts to promote the transition to renewable energies or, as proposed here, increased efforts to foster demographic renewal. Considering the relative merits of these various goals would require a different book than this one.

\subsection{Summary Part 2: Stability and Utopia}

The Great Divergence described in the first part of our book gets expressed in the Fundamental Equation of Steady-State Capital Theory:

$$
L+T=Z-D
$$

The period of production $T$, i.e., relative real capital requirements, remains constant over time; the waiting period $Z$, i.e., relative desired wealth, increases over time - and it does so worldwide. The growing divergence between the relative wealth desired by private persons and constant relative capital requirements has to be bridged over by a growing public debt period $D$, if the goal of price stability at full employment, i.e., of a non-negative real interest rate, is to be maintained.

If our analysis is theoretically and empirically correct, then it requires "new thinking" about the long-term economic and social conditions for an "open," democratically constituted society. In Chaps. 9 and 12, we try to make a start in such "new thinking." On the basis of historical and also very recent experience, Chap. 9 examines some (but by no means all) functional conditions of the democratically constituted Open Society. The structure of the welfare state is key here. Reduced to a simple formula, the welfare state is a condition for the coexistence between a democratic social order and the only known form of economic life that really works and constantly brings about material progress: the market economy.

On the other hand, the welfare state should not be overextended, if we do not want to destroy the system of incentives proper to a market economy. But to prevent the danger of an overgrown welfare state from becoming reality, it has to be possible for people to make provision for their own future. They have to be able to believe in the principle of subsidiarity. They have really to want to take responsibility for their futures. Monetary stability is key for this. It makes abstract saving possible for the individual in the form of purchasing power that can be mobilized in future. This is the real purpose of price stability. Price stability is not some neoliberal fad of a few economics professors. It is the basis on which citizens are able to grasp their duty to provide for their own futures and it is a constant reminder of this duty. For while it is true that "ultra posse nemo obligatur"- no one can be 
obligated beyond what is possible - it is price stability that ensures that the "posse" is satisfied: citizens can provide for their own futures.

Now, you may ask: What is the "new thinking" on price stability here? The answer is that it is the relationship between the objective of price stability and the incurring of public debt that has to be rethought. For proponents of free markets, the defense of price stability usually goes together with a critical attitude toward public debt. This is in no small measure due to the historical experience that governments have again and again used inflation to shift the burden of public debt from the state to its creditors. Price stability and public debt are here opposed to one another: There is "either price stability or public debt."

But the Great Divergence calls for increasing public debt to stabilize full employment, and this postulate makes public debt and price stability into allies. They are no longer opposed to one another, but rather complementarity to one another. It is logically conceivable that full employment could be brought about without increasing relative public debt: namely, by striving for negative real interest rates. This would go together with inflation, in order to get around the zero lower bound of nominal interest rates. De facto, savers are thus deprived of the possibility of investing their money in risk-free financial instruments of stable real value. This provokes a "flight to tangible assets," which is connected to greater overall investment. But taking refuge in tangible assets is only an apparent solution to the problems. Firstly, such investment is economically unproductive; secondly, it is extremely dangerous for the stability of the economic and social order when people are denied the possibility of making provision for their future by means of investment instruments of stable value. The call for government intervention will then become too strong to ignore. And such intervention will overwhelm the state's capacities. Democratic elections will then lead to a rejection of the market economy: ultimately, with extremely high costs in terms of both material standard of living and personal freedom.

This is what makes public debt into an ally of price stability. The epitome of price stability is a non-negative, risk-free real rate of interest. But the latter is only compatible with full employment if the desired wealth of private citizens (represented by the waiting period $Z$ ) is made compatible with the lower capital requirements of the system of production (represented by the period of production T) by sufficiently high net public debt. This is what was shown in Chap. 9 .

In Chap. 12, we undertook an exercise in the "new thinking" in considering the developing countries. For conventional thinking, developing countries immediately bring to mind "development aid" in the form of financial assistance. We use the example of China as developing country, in order to turn this association completely around. The rapid rise of China in recent decades has, as it were, been connected to financial assistance for the rich countries. China's current account balance has long been positive, and it is at times very substantially so. The Chinese central bank is by far the largest creditor of the US Treasury. These high net capital exports of the Chinese economy go together with China's extremely successful exporting of goods. China has used the opportunity of free trade to raise its standard of living and create domestic jobs. By exporting, China has familiarized itself with 
the commercial practices of the rich countries: "Learning from customers" has been the Chinese recipe for success in recent decades.

In our admittedly "utopian" Chap. 12, we apply the Chinese model to all the developing countries. Our position is that the best development aid that the rich countries can provide to the poorer countries is a massive increase in imports from them. Two main instruments can facilitate this. (1) The elimination of many import barriers to goods and services from developing countries. (2) Maintaining an exchange rate between the currencies of the rich countries (the "dollar") and the currencies of the poor countries (the "rupee") that makes it easier for developing countries to export to the rich countries and to replace imports from the rich countries with their own products.

It is thanks precisely to the Great Divergence that this sort of promotion of growth in the developing countries is possible, in principle, without sacrificing full employment in the rich countries. At persistently low interest rates, public debt in the rich countries can be further increased, in order to make room for goods and services from the developing countries without the rich countries having, on balance, to suffer job losses.

This is, however, utopian. For it is only on balance that unemployment is avoided in the rich countries. Numerous jobs in the rich countries would fall victim to such a strategy. The new jobs that come into being to replace them would be overwhelmingly found in other sectors. And the jobs being lost are concrete, whereas the new jobs to come cannot be identified in advance. Hence, they are abstract. The interest group connected to the concrete, existing jobs will oppose such a policy, and there is not any interest group for the future, but today still abstract jobs.

Nonetheless, as an exercise in "new thinking," this sort of utopian scenario is useful.

\subsection{Fiscal Policy as Steering Instrument: The Appropriate Real Interest Rate}

In the Friedman world, the central bank steers the economy by way of its monetary policy, which is today primarily interest rate policy. In doing so, it is helped by the "automatic stabilizers" in the government budget: The deficit is bigger or smaller depending on the economic situation. Hence, disposable income and (after tax) corporate profits fluctuate less than national product. We will not go into the structural, microeconomic details of the functioning of this automatic stabilizer here. The keyword is "market asymmetry." The prices of goods are predominantly higher than the short-term marginal costs. Sellers are structurally hungry for transactions, whereas buyers are, for the moment, satiated after the transaction has been completed. Thus, in macroeconomic terms, national product and aggregate demand dance in tandem. As Hayek (1945) teaches, prices are signals of scarcity with whose help productive cooperation between people can succeed despite 
knowledge being dispersed in society. But knowledge about prices is also dispersed and therefore imperfect. Adapting to this imperfection leads to the abovementioned market asymmetry. It makes possible the synthesis of Hayek and Keynes (Weizsäcker 2005). And it makes possible neo-Keynesian macroeconomics (Woodford 2003).

Cyclical fluctuations that are too strong to be offset by interest rate policy alone can already occur in the Friedman world of a positive natural rate of interest. In other words, the problems cannot be solved just by "Taylor rules" (Taylor 1993). Hence, policymakers have long used fiscal policy as an additional steering instrument. At other times, it was, however, precisely fiscal policy itself that contributed to destabilizing the economy.

In Chap. 10, we showed that in the Friedman world, fiscal policy can, in principle, be an autonomous national competence. We also showed that this is not the case in the Keynes world. In the Keynes world, citizens' politically articulated interests as producers outweigh their politically articulated interests as consumers. This is why there is the potential here for politically virulent controversy about the "international distribution of jobs." The aim of our proposal for a balanced account agreement is to save free international trade despite this conflict potential. If all countries' current accounts are balanced, then we can speak, at least as an approximation, of a "fair international distribution of jobs."

We want now to discuss some basic ideas for the architecture of the international balanced account agreement.

The first step is to set a common international target interest rate for government bonds with a high (or the highest) credit rating. This should be expressed as real interest rate, since it has to be possible to compare it to the growth rate of the OECD plus China region. The advancing of the Keynes world at the expense of the Friedman world is based on the Great Divergence. The significance of net public debt for citizens is increasing over time. This has been explained in detail in the present book. Therefore, the significance of the interest rate at which the government can borrow is also increasing. In the interest of the stability of the economy as a whole, this rate should not be too high.

We regard the overall growth rate of the economy as a critical point of reference for the real interest rate. In our analysis, this overall growth rate is, more precisely, the steady-state growth rate of the OECD plus China region. It can be estimated to be between 2.5 and $3 \%$ per year. If the government has to pay an interest rate that is higher than the steady-state growth rate, then the budget has to have a primary surplus in the steady state. For reasons of stability, this strikes us as problematic. A non-positive or even negative primary balance should be strived for.

An interest rate equal to the growth rate maximizes the steady-state wealth of the representative citizen - provided that the interest rate at which the government can borrow is the correct price signal for the marginal productivity of capital in the production sector and for the intertemporal substitution of consumption and labor supply in the consumption sector. Hence, there is some reason to steer toward the economy's growth rate as equilibrium interest rate. But besides maximizing steady-state prosperity, the stability of the overall system is also at issue. Hence, we 
propose that the targeted annual real interest rate should be one to one-and-a-half percentage points $(1-1.5 \%)$ lower than the growth rate of the area in question. According to current estimates, this would imply a real interest rate of $1.5 \%$ per year for the OECD plus China region.

What we mean is, of course, the interest rate after taxes. For allocation decisions are determined by after-tax interest rates in both the system of production and the system of consumption. If the average tax on interest income in the area as a whole is $25 \%$, then the real pre-tax interest rate to be strived for would be two percent per year.

According to our approximation formula

$$
\Omega=\frac{1}{2}(r-g)^{2}\left\{\psi T^{2}+\gamma Z^{2}\right\}
$$

at a targeted international real interest rate of $r=1.5 \%$ per year on the highest-rated public debt and a growth rate $g=2.5 \%$ per year, the loss in prosperity relative to the "optimal" interest rate $r=g$ amounts to less than one percent, if we use the values $\psi=1, \gamma=1.5, T=4$ and $Z=10$ and $g-r=1 \%$ per year, which correspond to our empirical estimates. At $g=3 \%$ per year and hence $g-r=1.5 \%$ per year, we would obtain a loss in prosperity of just under two percent. This sacrifice of steady-state prosperity is worth it to us, if the stability of the system of public debt can thus be better secured. We derived the values for the variables used here in Chap. 8.

If further research comes to the conclusion that the risk-free real interest rate $r$ for public debt is lower than the marginal productivity of capital, then the steady-state loss in prosperity that results from maintaining a safety margin of $1-1.5 \%$ lower than the growth rate would be even less than is calculated using the formula for $\Omega$. For, in this case, the prosperity-maximizing steady-state interest rate is itself lower than the growth rate (cf. Sect. 2.10).

\subsection{Fiscal Policy as Steering Instrument: The National Level}

In keeping with the "philosophy" of the proposed balanced account agreement, it is the duty of countries with current account surpluses to act when real interest rates are low. Conversely, at high real interest rates, it is the duty of countries with current account deficits to act. The boundary between low and high interest rates is the internationally agreed target level of the real interest rate. We have proposed an after-tax interest rate of $1.5 \%$ per year as target. In what follows, we call this targeted real interest rate level $r^{*}$. National interest rate levels may, of course, differ from the international real interest rate level. In particular, the national nominal, and perhaps also real, interest rate level may deviate from the international real interest rate level due to the fact that the country in question has a lower credit rating and 
hence has to pay higher interest than countries with the best credit rating. The following rule should principally apply for countries with the highest credit rating.

Let $X$ represent a country's current account balance as a percentage of domestic consumption. $X$ is thus a dimensionless variable, since it is a coefficient of two variables that have the same dimension: namely, $€ /$ year. Recall that in a closed economy, such as the OECD plus China region in our treatment, the equilibrium real interest rate $r$ is an increasing function of the debt period $D$ in the steady state. Hence, if, at low interest rates $r<r^{*}$, the countries with a current account surplus increase their public debt period and the countries with a current account deficit hold their public debt period constant, then the average public debt period of the area rises. We can thus expect a rising real interest rate $r$. Conversely, if, at high interest rates $r>r^{*}$, the countries with a current account deficit reduce their public debt period, whereas the countries with a current account surplus maintain their existing public debt period, then average relative public debt falls and, as consequence, so too does the interest rate level. The effect of the balanced account agreement is thus to bring the interest rate level closer to its target value.

The rule that we propose has the following general form. The steering variable that we are considering is the time derivative of the debt period $D$. We designate it as $\dot{D}$. Now, we propose that:

1. If $X>0$ and $r^{*}>r$, then $\dot{D}=m\left(r^{*}-r\right)^{2} X^{2}, m>0$ should apply.

2. If $X<0$ and $r>r^{*}$, then $\dot{D}=-m\left(r-r^{*}\right)^{2} X^{2}, m>0$ should apply.

It is a good idea to make the standard deviations $r^{*}-r$ and $X$ quadratic in the provisions, so that the provisions have a disproportionately strong effect for large deviations as compared to small deviations.

The question of the appropriate size of the proportionality parameter $m$ would need be studied more closely. Using simulation models would probably be the best way to do so.

As already noted above, such an agreement does not represent too painful a restriction of countries' freedom of action, since a debt policy of the sort prescribed by it is in any case in the interest of each of the countries concerned. But such an internationally agreed rule does, of course, restrict their freedom of action. This is, however, a feature of all binding international agreements. Despite this fact, such agreements are frequently concluded, because every party expects advantages from the obligations placed upon the others. This will normally be the case here too: If Germany, by accepting the obligation to use fiscal policy to make its current account more balanced, obtains the agreement of other countries to show greater fiscal responsibility and, furthermore, to do nothing against global free trade, then the advantages of this agreement for Germany far outweigh any possible disadvantages associated with it.

Such a balanced account agreement would undoubtedly bring about anticipation effects. If countries with current account deficits know that Germany will soon be rolling back its export surpluses by way of a more expansionary fiscal policy, then the other countries - whether other European countries or countries in North 
America or East Asia - will act differently in anticipation of this fact. If Italian or Greek voters know that Germany will soon be rolling back its export surpluses, then the populist slogan that the euro is a ploy to "steal" jobs from Mediterranean countries will evaporate.

Let us dispose of one theoretical objection to our proposal for an international balanced account agreement right away. Anyone who persists in believing in "Ricardian equivalence" à la Barro (1974) will object that a current account surplus cannot be reduced by more public debt nor a current account deficit by less public debt, because, in anticipation of additional taxes to repay the increased debt, citizens will save more, so that aggregate domestic demand does not rise at all. Of course, every good economist knows that the derivation of the Barro-Ricardo effect requires an interest rate greater than the growth rate of the economy. But the Great Divergence, which is the key to our whole approach, is incompatible with the assumption of a long-term, risk-free interest rate that is greater than the rate of growth.

\subsection{A Replacement for the Debt Brake}

In a single country without foreign relations, it is conceivable that, despite the Great Divergence, the constitution might require the use of a debt brake of the sort found in the German constitution or "Basic Law." For this debt brake only relates, after all, to the "tip of the iceberg" of all public debt. We have demonstrated this both theoretically and empirically in the first part of our book: The implicit public debt entailed by the present form of the welfare state is far greater than explicit public debt. Hence, if a country wants to make the ratio of explicit public debt to annual national product tend toward zero by using a "debt brake" and wants this, nonetheless, to be compatible with the secular increase in relative desired wealth and the constant capital coefficient, then there is no other option than gradually expanding implicit public debt even more. Entitlements to retirement benefits are the main component of the latter. One would thus make the value of these entitlements rise in parallel to the rise in citizens' relative desired wealth. It is not our intention to discuss how such a policy could be practically implemented in legislation. Whether, however, it represents the apex of wisdom can be doubted. It may well be a feasible public debt policy, but far from an optimal one.

In any case, this model of a single, isolated country has nothing to do with the political-economic reality of a globalized world economy. Referring to Chap. 11, we showed above that in the age of the Keynes world and the "New Trade Policy," the debt brake is structurally incompatible with a stable euro. This is because it is incompatible with full employment in the euro area.

Our proposed balanced account agreement is to be understood as a replacement for the debt brake. It creates other obligations for German fiscal policy. But the obligation to pursue a stability-oriented fiscal policy remains. Countries should still not overdo it with their public debt. But now there is not only a cyclical signal for 
fiscal policy, as is already the case today, but also an equally important "price signal" for fiscal policy. This price signal is the interest rate.

And, unlike the debt brake, the balanced account agreement takes the new conditions of the Keynes world into account. As a result of the continuing rise in relative desired wealth, the latter has superseded the Friedman world. With sound fiscal policy, a return to the Friedman world of high real interest rates is not to be expected. Nonetheless, voters' interests as producers are paramount in the Keynes world. And they are thus decisive for international trade relations. The balanced account agreement takes this into account. The debt brake has no adequate response to it. The balanced account agreement can do justice to the slogan of a "fair international distribution of jobs," but the debt brake cannot.

\subsection{Conclusion: $L+T=Z-D$ Requires New Thinking}

Steady-state capital theory, with its fundamental equation $L+T=Z-D$, is the theoretical entryway to the Great Divergence between the period of production $T$, which is constant over time, and relative desired wealth $Z$, which increases over time in parallel to growing prosperity. This Great Divergence is also empirically supported. As long as we understand that explicit public debt is only the tip of the iceberg of all public debt, we can recognize that the volume of the latter, as represented by the public debt period $D$, has already grown to a half-dozen years of total consumption today. Relative desired wealth has already raced this much ahead of the relative private real assets that can be productively used. And $Z$ will continue to grow - and it makes sense for $D$ to grow with it. For technical progress (digitization, artificial intelligence, progress in medicine, 3-D printing, etc.) appears to be accelerating rather than slowing down, and it seems that this technical progress tends to reduce the relative amount of capital tied up in the production process-i.e., $T$-rather than increase it. Just looking at gross investment is misleading. Depreciation is rising even faster.

This is why new thinking is needed. Price stability and public debt are no longer opponents; they are now friends, and they will continue to be in future. The question of the stability of public finances needs a different answer than the debt brake today.

In this book, we have taken some first steps on the terrain of the required new thinking. But there is still a great deal more to be done by economics as a discipline. 


\section{References}

Barro, Robert J. 1974. Are Government Bonds Net Wealth? Journal of Political Economy 82 (6): $1095-1117$.

Hayek, Friedrich A. von. 1945. The Use of Knowledge in Society. American Economic Review 35 (4): 519-530.

Taylor, John B. 1993. Discretion Versus Policy Rules in Practice. Carnegie-Rochester Conference Series on Public Policy 39: 1--214.

Weizsäcker, Carl Christian von. 2005. Hayek und Keynes: Eine Synthese. Ordo 56: 95-111.

Weizsäcker, Carl Christian von. 2021. Capital Theory of the Steady State - Or: $T+\mathrm{L}=\mathrm{Z}-\mathrm{D}$. https://www.coll.mpg.de/Weizsaecker/CapitalTheory2021 and https://www.springer. com/97836 58273620 .

Woodford, Michael. 2003. Interest and Prices: Foundations of a Theory of Monetary Policy. Princeton (NJ): Princeton University Press.

Open Access This chapter is licensed under the terms of the Creative Commons Attribution 4.0 International License (http://creativecommons.org/licenses/by/4.0/), which permits use, sharing, adaptation, distribution and reproduction in any medium or format, as long as you give appropriate credit to the original author(s) and the source, provide a link to the Creative Commons license and indicate if changes were made.

The images or other third party material in this chapter are included in the chapter's Creative Commons license, unless indicated otherwise in a credit line to the material. If material is not included in the chapter's Creative Commons license and your intended use is not permitted by statutory regulation or exceeds the permitted use, you will need to obtain permission directly from the copyright holder.

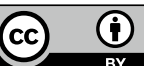

